\title{
In Response to "Estimation of Disease Activity in Rheumatoid Arthritis: A Correlation Study between Clinical, Inflammatory Markers and Power Doppler Ultrasonography"
}

\author{
Kaushik Basu ${ }^{1}$ \\ Bengal Physician Journal (2021): 10.5005/jp-journals-10070-7046
}

Dear Sir,

I have read with interest the study titled "Estimation of Disease Activity in Rheumatoid Arthritis: A Correlation Study between Clinical, Inflammatory Markers and Power Doppler Ultrasonography" by Sarkar et al., published in your esteemed journal. Indeed, highresolution ultrasonography with power Doppler has changed the way we look at remission in rheumatoid arthritis. ${ }^{2}$

However, there are some omissions that have rendered the statistics quoted in the study quite indecipherable, and the study weak.

- Though I presume the numerical values of correlation provided in Table 1 represent the correlation coefficient $\left(r^{2}\right)$, the level of significance $(p)$ has not been mentioned. Without knowing the level of significance, the correlation becomes unclear.

- Methods should have indicated and omitted any patients who have received previous single or multiple intra-articular injections as they may have decreased synovitis and reduced power Doppler signals.

- Mentioning the disease duration or having a cutoff for disease duration would have helped a lot in deciphering the correlation or lack of it, and when it comes to the correlation between synovitis and Erythrocyte sedimentation rate (ESR), $C$ reactive protein (CRP), Tender joint count (TJC), and Swollen joint count (SJC), it is seen many a time that deformed joints can seem to be tender or swollen but is void of synovitis and power Doppler signals.

However, I must congratulate the authors of the article for taking up a very pertinent and clinically relevant topic for research.
${ }^{1}$ Department of Rheumatology, Medical College, Kolkata, West Bengal, India

Corresponding Author: Kaushik Basu, Department of Rheumatology, Medical College, Kolkata, West Bengal, India, Phone: +9038831211, e-mail: phoenix.0013@gmail.com

How to cite this article: Basu K. In Response to "Estimation of Disease Activity in Rheumatoid Arthritis: A Correlation Study between Clinical, Inflammatory Markers and Power Doppler Ultrasonography". Bengal Physician Journal 2021;8(1):29.

The data regarding high-resolution ultrasosography with power doppler (USG-PD) in rheumatoid arthritis are scarce in our country in particular, and this study, with the above clarifications and corrections, will definitely add to the knowledge base of research in the field of rheumatology.

\section{References}

1. Sarkar TS, Gantait K. Estimation of disease activity in rheumatoid arthritis: a correlation study between clinical, inflammatory markers and power Doppler ultrasonography. Bengal Phys J 2021. DOI: 10.5005/jp-journals-10070-7038.

2. Lack of association between clinical and ultrasound measures of disease activity in rheumatoid arthritis remission. Ther Adv Musculoskelet Dis 2020;12:1759720X20915322. DOI: $10.1177 / 1759720 \times 20915322$.

\footnotetext{
(c) The Author(s). 2021 Open Access This article is distributed under the terms of the Creative Commons Attribution 4.0 International License (https:// creativecommons.org/licenses/by-nc/4.0/), which permits unrestricted use, distribution, and non-commercial reproduction in any medium, provided you give appropriate credit to the original author(s) and the source, provide a link to the Creative Commons license, and indicate if changes were made. The Creative Commons Public Domain Dedication waiver (http://creativecommons.org/publicdomain/zero/1.0/) applies to the data made available in this article, unless otherwise stated.
} 